\title{
АНАЛІЗ МЕТОДИК ОЦІНКИ РІВНЯ БЕЗПЕКИ РУХУ ПОЇЗДІВ НА ЗАЛІЗНИЧНОМУ ТРАНСПОРТІ
}

Канд. техн. наук О.В. Розсоха, магістранти М.С. Конотопська, О.А. Шабатіна, С.З. Вітола

\section{АНАЛИЗ МЕТОДИК ОЦЕНКИ УРОВНЯ БЕЗОПАСНОСТИ ДВИЖЕНИЯ ПОЕЗДОВ НА ЖЕЛЕЗНОДОРОЖНОМ ТРАНСПОРТЕ}

Канд. техн. наук А.В. Розсоха, магистранты М.Е. Конотопская, О.А. Шабатина, С.З. Витола

\section{ANALYSIS OF METHODS OF ASSESSING THE LEVEL OF SAFETY OF MOVEMENT OF TRAINS ON RAILWAY TRANSPORT}

\author{
Doctor of Science (Ph.D.) A. Rozsokha, magistrands M. Konotopska, O. Shabatina, S. Vitola
}

У статті проведено аналіз методів оцінки рівня безпеки руху поїздів на залізничному транспорті Украӥни. Існуючі наукові підходи до його визначення спрямовані на отримання результату за окремою групою показників. Комплексному підходу при оиіниі рівня безпеки руху в теперішній час уваги не приділено. Підвищення якості безпеки руху потребує розроблення нових підходів при підготовці чинної системи управління безпекою руху поїзів.

Ключові слова: безпека руху поӥздів, ефективність роботи залізниць, системи управління.

В статье проведен анализ методов оиенки уровня безопасности движения поездов на железнодорожном транспорте Украины. Существующие научные подходы к его определению направлены на получение результата по отдельной группе показателей. Комплексному подходу при оценке уровня безопасности движения в настоящее время внимания не уделяется. Повышение качества безопасности движения требует разработки новых подходов при подготовке действующей системы управления безопасностью движения поездов.

Ключевые слова: безопасность движения поездов, эффективность работы железных дорог, системы управления.

In the article the analysis of methods to assess the level of safety of movement of trains on railway transport of Ukraine. Analysis of the safe movement of trains at all levels of the structure of railway transport of Ukraine is carried out mainly on the basis of the number of accidents committed on the railway network. Traffic safety is a comprehensive indicator that reflects the level of development of technique, technology, work organization, management and economy of railway transport. Existing scientific approaches regarding the determination of the level of security aimed at obtaining results on a separate group of indicators. An integrated approach when assessing the level of safety at the present time attention is not given. Improving the quality of traffic safety requires the development of new approaches in the development of the current system of management of safety of movement of trains based integrated approach.

Keywords: traffic safety, railway efficiency, control system.

Вступ. Залізничний транспорт України здійснюе значний обсяг пасажирських i вантажних перевезень. На сьогоднішній день стан виробничої бази і технологічний рівень перевезень залізницями за багатьма параметрами не відповідають повною мірою вимогам суспільства, світовим та європейським стандартам якості транспортних послуг.
Одним з важливих чинників, що повинні забезпечити конкурентоспроможність залізничного транспорту на ринку перевезень, $\epsilon$ безпека руху. Вона пов'язана із захистом життя й здоров'я пасажирів, забезпеченням цілісності вантажів, охороною навколишнього природного середовища. 
Постановка проблеми. Безпека руху на залізничному транспорті є однією 3 важливих проблем, оскільки без належного ії рівня функціонування залізничного сегменту неможливе. В транспортній стратегії України на період до 2020 року йде мова про те, що рівень безпеки не відповідає сучасним вимогам до ii забезпечення. Ураховуючи зазначене, актуальними $є$ дослідження, які спрямовані на підвищення рівня безпеки руху поїздів на залізничному транспорті України [1].

Аналіз досліджень і публікацій. Значний внесок у побудову принципів створення i розвитку теорії безпеки руху залізничного транспорту зробили такі вчені, як Бутько Т.В., Болотний В.Я., Грау Б., Грунтов П.С., Замишляєв О.М., Кобзєв В.А., Кочнєв Ф.П., Лисенков В.М., Модін М.К., Негрей В.Я., Образцов В.М., Правдін М.В., Сапожніков В.В., Сотніков І.Б., Страковський I.I., Шабалін М.Г. та ін. [2-4].

Наукові підходи до визначення рівня безпеки руху на залізничному транспорті були в основному спрямовані на отримання результату за окремою групою показників. Комплексному підходу до оцінки рівня безпеки руху уваги майже не приділялось.

Формулювання мети (постановка завдання). Метою цієї статті $є$ підвищення ефективності функціонування залізничного транспорту шляхом комплексної оцінки стану безпеки руху. Для цього необхідно розглянути діючі методи її оцінки та визначити напрямки їх удосконалення.

Аналіз існуючих методик оцінки рівня безпеки руху на залізничному транспорті. Згідно 3 діючим Положенням про систему управління безпекою руху поїздів на залізницях України (Наказ Міністерства інфраструктури України від 01.04.2011 р. за № 27) показниками оцінки стану безпеки руху поїздів є кількість транспортних подій на 1 млн привед. ткм; загиблих на 100 подій; травмованих на 100 подій. У цьому документі зазначено, що 3 урахуванням значення прийнятного ризику всі підприємства та структурні підрозділи Державної адміністрації залізничного транспорту України, які підлягають нагляду (контролю), належать до одного 3 трьох ступенів ризику: високого, середнього та низького. Критерії оцінки ступеня ризику затверджені постановою Кабінету Міністрів
України від 17.04.2008 р. № 365, у якій відсутні числові межі ризику та методика їх розрахунку.

При проведенні аналізу на залізницях існують і інші показники, що відображаються у звітах, а саме: кількість виявлених зауважень, які виявлено при перевірках; кількість працівників, яких притягнуто до дисциплінарної відповідальності за результатами перевірок; кількість зауважень, що виявлено при комісійних місячних оглядах; грошові витрати при виникненні транспортних подій та ін. На жаль, при наявності цілого ряду показників комплексно оцінити стан з безпеки руху на полігоні залізниць неможливо, особливо, коли на ряді залізничних станцій за певний період не скоєно транспортних подій.

На російських залізницях у 2009 році затверджено «Методичні рекомендації по застосуванню у ВАТ «РЖД» системи гармонізованих показників для оцінки безпеки руху поїздів та системи організації діяльності по обліку та використанню цих показників» [5]. У тому ж році у ВАТ «РЖД» розроблено методики визначення рівня безпеки руху на основі статистичного аналізу та індексів оцінки ситуації для локомотивного господарства, господарств перевезень та колії [5-8].

У зазначених методиках зроблено акцент на визначення показників допустимого та поточного ризику. Показники допустимого ризику слід розглядати як показники ризику, які можна вважати прийнятними при існуючих суспільних цінностях, та ті, що являють собою оптимальний баланс між рівнем безпеки, вимогами задоволення перевізного процесу, а також такими факторами, як вигідність для користувачів залізничним транспортом, ефективність витрат ВАТ «РЖД» та ін.

Допустимий ризик оцінюється ступенем його відповідності показникам, які характеризують частоту виявлених подій за звітні періоди (виражені відносним числом подій у розрахунку на 1 млн поїзд.км) і згідно 3 [5] знаходиться за формулою

$$
P_{R}=\frac{C_{N}}{\Pi_{N} \cdot R_{N}},
$$

де $C_{N}$ - загальне число транспортних подій у відповідному господарстві за звітний період $N$; $\Pi_{N}$ - загальне число поїздо-кілометрів за розрахунковий період $N$, млн поїзд.км; $R_{N}-$ 
значення цільових показників безпеки руху за розрахунковий період $N$ [5].

Дана методика не дає змоги визначити фактори, що впливають на рівень безпеки, а це не дає можливості для розроблення відповідних заходів, які направлені на підвищення безпеки перевізного процесу.

Більш сприятливою для практичної реалізації $є$ методика визначення рівня безпеки руху на основі статистичного аналізу та індексів оцінки ситуації [5-8]. Визначення індексів оцінки ситуації виконується в п'ять етапів. Необхідно розуміти, що тільки за допомогою оцінки впливу факторів на виникнення транспортних подій неможливо запобігти виникненню всіх транспортних подій. Це пов'язано в першу чергу з тим, що наявність навіть одного фактора може обумовити виникнення випадку транспортної події. Якщо ж розглядати не поодинокі випадки, а сукупність транспортних подій у цілому по господарству, то можна сказати, що оцінка впливу факторів дає змогу визначити концентрацію транспортних подій у вигляді найбільш вірогідної безлічі. Саму ж практичну роботу із запобігання виникненню транспортних подій можна буде організувати виключно за тими їх видами, вплив на які надають певні, чітко вимірювані фактори, наявність або відсутність яких може бути зафіксовано в рамках діючих технологій.

Якість оцінки впливу факторів на виникнення транспортних подій багато в чому залежить від ступеня достовірності первинної інформації. При відсутності (або недостовірності) первинних даних про поточний стан впливу факторів підсумкові висновки про небезпеку виникнення транспортних подій того чи іншого виду у відповідному структурному підрозділі будуть недостовірними. Дана методика також не знайшла практичного застосування на підприємствах залізничного транспорту Росії. Перш за все перешкодою до реалізації методик на підприємствах господарств перевезень, колії та локомотивного $\epsilon$ недостатність статистичного матеріалу. Однак навіть при його наявності $\epsilon$ цілий ряд інших причин, що роблять методики мало придатними, до яких належать такі:
- не прописана процедура встановлення рейтингів для виділених факторів;

- не прописаний алгоритм розрахунків;

- відсутня методологічна єдність (передбачені різні підходи в кожній з методик при розрахунку гранично допустимого рівня);

- не прописана процедура розрахунку коефіцієнта (ваги) впливу групи на появу тієї чи іншої події. Значення коефіцієнта повинно обов'язково мати обгрунтування, а також повинен бути встановлений період їх перегляду;

- логічна невідповідність між факторами груп «Тополого-технологічні і кліматичні фактори», «Технічні фактори», де ставиться питання «Що призводить до виникнення події?», та факторами групи «Кількість транспортних пригод», де передбачається запитання «Скільки відбулося?».

Зазначені вище причини роблять дану методику незручною у практичному застосуванні, не дають можливості отримання порівняльної та узагальненої картини в цілому. Також у даній методиці відсутні розрахунки наслідків подій при розрахунку оцінки ситуації.

На підставі цього необхідний інший методичний підхід, що усуває перешкоди до реального його використання, робить його в рівній мірі прийнятним для різних підприємств і господарств залізниці.

Висновки. Аналіз стану безпеки руху поїздів на всіх рівнях структури залізничного транспорту України проводиться в основному на підставі кількості транспортних подій, що скоєно на мережі залізниць. Безпека руху $\epsilon$ комплексним показником, який відображає рівень розвитку техніки, технології, організації праці, управління та економіки залізничного транспорту. Існуючі наукові підходи щодо визначення рівня безпеки спрямовані на отримання результату за окремою групою показників. Комплексному підходу при оцінці рівня безпеки руху в теперішній час уваги не приділено. Підвищення якості безпеки руху потребує розроблення нових підходів при підготовці чинної системи управління безпекою руху поїздів 3 урахуванням комплексного підходу [9-10]. 


\section{Список використаних джерел}

1. Транспортна стратегія України на період до 2020 року [Електронний ресурс]. - Режим доступу: http://zakon4.rada.gov.ua/laws/show/2174-2010-p.

2. Лисенков, В.М. Статистическая теория безопасности движения [Текст] / В.М. Лисенков. М.: ВИНИТИ РАН, 1999. - 325 с.

3. Лисенков, В.М. Безопасность технических средств в системах управления движением поездов [Текст] / В.М. Лисенков. - М.: Транспорт, 1992. - 192 с.

4. Горелик, А.В. Модель оценки безопасности систем железнодорожной автоматики по параметрам движения поездов [Текст] / А.В. Горелик, Н.А. Тарадин, П.А. Неваров // Наука и техника транспорта. - 2008. - № 4. - С. 30-36.

5. Распоряжение ОАО «РЖД» № 562p от 20.03.2009 г. Методические рекомендации по применению в открытом акционерном обществе «Российские железные дороги» системы гармонизированных показателей для оценки безопасности движения поездов и системы организации деятельности по учету и использованию этих показателей [Электронный ресурс]. - Режим доступа: http://www.samgups.ru/pod/kafedr/kafiue/bp/informatsionnyy_tsentr/strategiya_obespecheniya_garantirovan noy_bezopasnosti_i_nadezhnosti/rasporyazhenie_562.PDF.

6. Методика определения уровня безопасности движения на основе статистического анализа и индексов оценки ситуации для хозяйства перевозок ОАО «РЖД» [Электронный ресурс]. - Режим доступа: http://railway.kanaries.ru/index.php?act=attach\&type=post\&id=18468.

7. Методика определения уровня безопасности движения на основе статистического анализа и индексов оценки ситуации для локомотивного хозяйства ОАО «РЖД» [Электронный ресурс]. Режим доступа: http://railway.kanaries.ru/index.php?act=attach\&type=post\&id=18468.

8. Методика определения уровня безопасности движения на основе статистического анализа и индексов оценки ситуации для путевого хозяйства ОАО «РЖД» [Электронный ресурс]. - Режим доступа: http://railway.kanaries.ru/index.php?act=attach\&type=post\&id=18468.

9. Розсоха, О.В. Аналіз функціонування системи управління безпекою руху поїздів на залізницях України [Текст] / О.В. Розсоха, М.В. Люлін, О.В. Щербина // Залізничний транспорт України. - 2013. - № 5/6. - С. 21-25.

10. Замышляев, А.М. Повышение безопасности движения на основе комплексной оценки состояния инфраструктуры железнодорожной станции [Текст]: дис... канд. техн. наук: 05.22 .08 / А.М. Замышляев. - М., 2005. - 291 с.

Рецензент д-р техн. наук, професор С.С. Альошинський

Розсоха Олександр Володимирович, кандидат технічних наук, доцент кафедри залізничних станцій та вузлів, Український державний університет залізничного транспорту. Тел.: (057) 730-10-42.

Конотопська Марина Євгенівна, Шабатіна Олена Анатоліївна, Вітола Соломія Зіновіївна, магістранти кафедри залізничних станцій та вузлів, Український державний університет залізничного транспорту. Тел.: (057) 730-1042.

Rozsokha Olexandr, Associate Professor, Doctor of Science (Ph.D.), Ukraine State University of Railway Transport. Tel.: (057) 730-10-42.

Konotopska Maryna, Shabatina Olena, Vitola Solomiya, magistrands of Chair «Railway Stations and Junctions», Ukraine State University of Railway Transport. Tel.: (057) 730-10-42.

Стаття прийнята 02.07.2015p. 